\title{
Hypermarket customer loyalty: product attributes and image mediated by value and customer satisfaction
}

\author{
Astrid Puspaningrum \\ Brawijaya University, Economics and Business Faculty \\ Malang, Indonesia
}

\section{Keywords}

Product attributes, Image, Value, Customer Satisfaction and Loyalty.

\begin{abstract}
The purpose of this research to analyze the effect of product attributes and image on customer loyalty mediated by value and customer satisfaction. This research was conducted on the existing hypermarket customers in Malang City, namely, Carrefour, Giant and Sun hypermat by using sample size as many as 120 respondents. Sampling technique was done using Convenience sampling technique. The collected data were analyzed by using Structural Equation Model (SEM) with a variance based or component-based approach involving Partial Least Square (PLS). The results showed that product attributes directly affect the loyalty of hypermarket customers in Malang City, while the image does not affect customer loyalty directly. This indicates that hypermarket image concerning the price offered is in accordance to the quality of goods and attributes attached to the same goods with the conditions that exist in the supermarket. This what makes the customers do not have the same level of loyalty regarding the imaging activity done. Customer value and customer satisfaction serve as a complete mediation of the indirect effect of the image on customer loyalty. However, customer value and customer satisfaction serve as partial mediation from the indirect effect of product attributes on customer loyalty.
\end{abstract}

Corresponding author: Astrid Puspaningrum

Email addresses for corresponding author: astrid@ub.ac.id

First submission received: $13^{\text {th }}$ March 2018

Revised submission received: $27^{\text {th }}$ May 2018

Accepted: $24^{\text {th }}$ July 2018

\section{Introduction}

Indonesia still becomes a heaven for retail business. Having a population of 237 million people, Indonesia is still considered as a big market. Therefore, it is not surprising that world-class retail giants, such as Sogo, Carrefour, Giant, and the last South Korean retail giant, Lotte Shopping, are racing to expand their business in Indonesia. Local players like Hypermart or Ramayana at the same time do not want to miss their market so they continue making strategic plans to maintain their businesses. Similarly, supermarket or mini store retailers never stop opening new stores.

The chairman of the Indonesian Association of Retailers or Aprindo Roy Nicholas Mandey said retail growth until the first half of 2017 has reached 3.7 percent and it is predicted that until the end of the year it will reach 7.5 to 8 percent and this is still below the second half of 2016 which grew by 9 percent

The low growth is caused by some factors such as the price of commodities which does not increase, the wage of the lower middle segment does not change, and there is shifting changes in shopping behavior that was formerly done by large baskets, now consumers shop with a small basket size, In addition, consumers now no longer go to the store, simply order online or with pickup service available in transportation applications. Changing shopping patterns that make costumers do not have monthly spending, butthey just spend enough expenditure as needed only.

Along with changes in consumer behavior, then one way to gain and maintain market share is to increase customer loyalty. It used to be that the main purpose of marketers was to satisfy and satisfy the needs and wants of better targeted consumers than competitors (Kotler, 2006), but such a goal has shifted because more importantly it is loyalty. For the company, achieving customer loyalty is a highly desirable thing because loyal customers will be more profitable than less loyal customers. This is in 
accordance with Pareto $80 / 20$ law stating that $80 \%$ of the company's profits are contributed by $20 \%$ of loyal customers (Chan, 2003).

Forming a loyal customer does not come by itself. It needs to be aligned between the expectations and reality that consumers get. With regard to customer loyalty, Kotler and Keller, (2012) revealed loyalty as a strongly held commitment to buy certain products or services in the future. Loyal customers use the company's products more and for longer. Losing a loyal customer can mean a loss of future customer revenue streams (Kotler and Armstrong, 2015).

Marketers recognize that customer loyalty is a very important boost for sales. According Cooil (2007) the appropriate indicator to conduct research in retail business is customer loyalty, because customer satisfaction will create customer loyal behavior. Loyalty and satisfaction can make customers more beneficial from the disappointing situations associated with certain goods or with stores (Anselmsson, 2006). In fact, the relationship between satisfaction and loyalty has largely proven to be the case literature. Much research has focused on a positive relationship between customer satisfaction and loyalty, with researchers. Loyalty, especially in retail business (Cooil, 2007). According to customers, companies that perform well are customers who are willing to make their first purchase and then wish to make subsequent purchases over and over again (Chan, 2003).

In order to keep customers loyal, hypermarket management needs to pay attention to products sold. Sometimes consumers find it difficult to distinguish high-quality goods from their physical appearance alone, especially if they are packaged in an attractive package. To avoid disappointment due to wrong perception in choosing the goods then many consumers tend to choose goods manufactured by wellknown manufacturers which has product quality assurance. Looking at the phenomenon, some retailers in Indonesia try to package the products they sell using private label of their own. This is done of course with the consideration that their company has a good image in selling quality products and this image is strongly embedded in the minds of consumers.

Carrefour as a major retailer has sold private label items in stores reaching 10 percent of the total items having the average of 40 thousand items per outlet. Almost 90 percent of Carrefour private label product suppliers are home industries. So, indirectly, Carrefour helped to grow the real sector. All over Indonesia, Carrefour has 4,000 suppliers. Of these, about 70 percent are SMEs (small and medium Enterprises).

Theoretically, private label is an element of product attribute. Product attributes are elements of the product that are considered important by consumers and used as the basis for making purchasing decisions. The product attributes include brand, packaging, warranty (guarantee) and service (Kotler and Armstrong, 2015). Meanwhile, according to Kotler (2006) product attributes are factors considered by the buyer when purchasing the product, such as price, quality, packaging, completeness of function (feature), design, service and after sales. If a product has attributes or traits appropriate to what its buyer expects then the product will be considered suitable and will be followed by repeated purchase actions by the consumer.

The result of empirical research about the relationship between product attribute and customer loyalty was done by Bennur and Jin (2009) which concluded that product attributes have an effect on consumer satisfaction and loyalty. Corsi and Rungie (2010) show that there is a positive and significant relationship of product attributes on consumer loyalty with stronger prices and packaging interacting in determining consumer loyalty. The same results are shown by Rajaguru and Matanda (2010) who found the evidence that product attributes such as product quality, price and availability of new products have a significant effect on customer loyalty. Meanwhile, different results are shown by Reddy and Azeem (2011) who found the evidence that product quality does not give a significant effect on loyalty.

Customer loyalty has an important role in a company. According to Griffin (2002) high customer loyalty is in accordance to the usual purchasing behavior shown by loyal customers. To get loyal customers, every retail must create a good image in the eyes of consumers because the image that consumers have toward the store will ultimately lead to consumer ratings of the existence of the store. Fostering and maintaining a strong image is essential for a service organization, if it is to attract consumers and maintain its loyalty (Bloemer and Ruyter.1998). 
A good retail image in the eyes of consumers creates a good retail name as well. A company will be seen through its image both negative and positive image. A positive image will give a good sense of the company's products and so it can increase the number of sales. On the contrary, the sales of a company's products will fall or lose if its image is viewed negatively by the community (Mardalis, 2005). Sunter in Mardalis (2005) believes that in the future customers will be able to distinguish a product of a certain company with other products just by looking at its image. Therefore, for a company it is very important to have a good image. With a good concept, a company can complete a good identity as well and ultimately it can lead to a high awareness, loyalty, and a good reputation. Image is a perception of retail. If the consumer's perception is positive to retail then it will create a continuous acceptance of quality to acceptance of value and the end product is the desire to buy the later repurchase.

The result of empirical research of the effect of image on customer loyalty proposed by Turkyilmaz and Ozkan (2007) proved that there is a positive and significant relationship between the image of a company with customer loyalty. Lu and Cai (2009) stated that image affects loyalty. The same result is presented by Cheng (2011) stating that attitude loyalty is influenced by service quality, store image, switching cost and customer satisfaction. Different result is shown by Beneke et al. (2011) who found an evidence that image does not affect customer loyalty.

The results of the research concerning the effect of product attributes and image on customer loyalty showed inconsistent results or the existence of a research . this current research is conducted to fill in the gap by adding intervening variables or mediation namely value and customer satisfaction.

Keeping customers loyal is required to provide total customer value. The concept of customer value is crucial to achieving marketing success and thus requires management attention. Customer value is the difference between the prospective customer's assessment of all the benefits and costs of an offer against the alternatives. Thus, the product is said to have a high value if it matches customer needs, wants, and demands (Kotler and Keller, 2012)

It is important for marketers to deliver and provide quality products in corder to create value for customers. Customer value is a perceived quality of the customer that is adjusted to the relative price of a product produced by a company (Slater and Narver, 1994). Success in getting customers and making customers aware and recognizining the value of services is a challenge for professional marketers. Consumers will compare the sacrifices incurred with what they get (Kotler 2006). Sacrifices issued by consumers can be money, time and effort to get goods from service providers. Consumers now become very choosy because they are well aware that they are true trump card holders and this is manifested through their loyalty, which in turn encourages every company to put its orientation on customer satisfaction as its ultimate goal. Manufacturers are now increasingly convinced that one of the keys to success to win the competition lies in its ability to provide total customer value through the delivery of quality products at competitive prices.

The role of customer value mediating the effect of product attributes on customer loyalty is based on the results of previous empirical studies conducted by Walter, A. et al. (2002) which concluded that product quality influences the value of customer relations, while Luarn and Hsin (2003) and Lee and Murphy (2008) in their research found the evidence that perceived value affects customer loyalty. Likewise, the effect of image on customer loyalty mediated by customer value is based on the results of empirical studies conducted by While Luarn and Lin (2003), Lee and Murphy (2008) found evidence that the perceived value of customers will affect customer loyalty.

In addition to customer value, the variable that is allegedly able to mediate the effect of product attributes and image on customer loyalty is customer satisfaction. As revealed by Spreng et al. (1996), it is stated that a product can satisfy the customer when it is judged to meet or exceed customers wishes and expectations. Kotler (2006) defines customer satisfaction as a person's likes or dislikes of a product after comparing the product's achievement with expectations.

Bloemer and Ruyter (1997) explained that satisfaction is often seen as the basis for loyalty. Satisfaction is the result of customer evaluation of a product by comparing whether the product received has been in line with expectations. Satisfaction can also be interpreted as a belief that comes after comparing reality with expectations. For customers who are lacking at the ability to compare the satisfaction is actually only partial. This can be caused by lack of experience or information obtained by 
consumers related to the product to be purchased. Mital and Baldasare (1998) suggested that poor performance on product attributes has a negative effect on satisfaction and good performance on product attributes has a positive effect on satisfaction. Meanwhile, Bloemer, et al. (1998), Oloughlin and Coenders (2002), and Luarn and Lin (2003) in their research found the evidence that customer satisfaction directly affects customer loyalty.

The existence of the effect of the image on customer loyalty mediated by customer satisfaction is based on the results of empirical studies conducted by Aaker and Keller (1990) which showed that a good image of the company is able to increase customer satisfaction of the company's products which then effect on loyalty. Oloughlin and Coenders (2002) and Lu and Cai (2009) concluded that the image affects loyalty.

The modern market is actually a business with a level of profit that is not too high, ranging from $7-15 \%$ of turnover. But this business has a high level of liquidity, because sales to consumers are made in cash, while payments to suppliers can generally be done gradually. Modern markets generally have a relatively strong bargaining position against their suppliers. This is because modern retailers, generally are large scale companies and extensive distribution channels, so that the purchase of goods to suppliers can be done in large numbers. A strong bargaining position provides many advantages for modern retailers. In addition to being able to get the convenience in terms of repayment period of goods, the discounted price will also be more easily obtained with such strong bargaining position. The advantages of this bargaining position that makes the modern market able to apply low prices and compete with traditional markets, but still able to maintain the convenience of its outlets.

Hypermarket is the main driver of modern retail development in Indonesia. The development of this hypermarket can already be felt in the city of Malang because the city of Malang serves as a city of students and tourism causes the city to be a new land for hypermarket to expand its wings and reap high profits. As hypermarkets and other retailers increase, competition between retailers and hypermarkets is also increasing. So, customer loyalty is something to note

\section{Theoretical Review \\ Customer loyalty}

According to Griffin (2002), it is stated that loyality is defined as non-random purchase expressed over time by some decision making unit". Based on the definition it appears that loyalty is directed to a behavior, which is indicated by regular purchases, based on the decision-making unit. Customer loyalty has an important role in a company, maintaining them means improving company performance. This is the main reason for a company to attract and maintain customers.

Customer loyalty can be measured by the following indicators; the willingness of customers to make the company the first choice, the willingness of customers to buy products offered by customers, the willingness of customers to invite others to buy, and the willingness of customers to tell about the good things about the company (Foster and Cadogan, 2000). While the indicators of customer loyalty according to Kotler \& Keller (2012) are Repeat Purchase (fidelity to purchase the product); Retention (Resilience to negative effect of company); referalls (referring totally to the company's essence). Trang T.M. Nguyen, et al (2007) revealed that loyal customers will consider a customer to be a loyal customer to a supermarket if the customer do the following things: shopping in this supermarket in the next few weeks, shopping in this supermarket is the first choice, will go shopping at this supermarket in the future, and will promote this supermarket for family and friends.

Sung Jin Yoo and Young Jae Chang (2005) revealed that customer loyalty is formed due to favorable wording, repetitive purchase and intention of repurchase. Meanwhile, Chen (2008) identified customer loyalty as the best choice for shopping, loyalty to hypermarkets, the desire to always shop in the hypermarket, the order of shopping options in the hypermarket, has a character where visitors are served quickly

\section{Customer satisfaction}

Satisfaction is defined as a person's pleasure or disappointment of comparing perceived product performance in relationships and expectations. In Kotler's other opinion of satisfaction, it is a function of perceived performance and expectations. If the performance of a product or service is lower than expected, consumers will feel dissatisfied. If the performance is in accordance with expectations then the 
consumer will feel satisfied, if the performance to exceed expectations, then the consumer will feel very happy (Kotler, 2006). By knowing the level of customer satisfaction, the company can anticipate the criteria of a product. Starting from experience, stories or information from friends / relations or other parties and promises given by marketers to a product, will form an expectation (expectation) for the customer. The expectation of the customer compared with the performance of a product will form two conditions, namely customer satisfaction (customer satisfaction) or customer dissatisfaction (customer dissatisfaction). According to Spraeng, et al (1996), customer satisfaction is measured based on expectations, perceived performance, and an assessment of the performance of the product or service consumed. Fornel et al (1996) used three items to measure customer satisfaction namely 1) Overal Satisfaction (satisfaction as a whole) is the result of evaluation and experience of current consumption derived from customs, constraints and standardization of service; 2) Confirmation of expectation is the level of conformity between performance and customer expectations and 3) Comparison of Ideal is product performance compared to ideal conditions according to customer perception

Maxwell K. Hsu et al. (2010) stated that customer satisfaction is measured on the following bases: feeling satisfied with the decision to shop at Hypermarket, the choice to shop at Hypermarket is wise, the shopping experience at Hypermarket is pleasant and satisfied with the products and services provided. Dong-Mo Koo, (2003) revealed that customers who are satisfied with the decision to buy products in this store will make a wise decision to buy products in this store, and when he finishes shopping and gets out of this store, he thinks he is doing the right thing

\section{Customer Value}

The concept of customer value provides an overview of a company's customers, considers what they want, and believes that they benefit from a product. Goetsch and Davis (2000) stated that organizations or companies should know what customers want, whether the product or the value of customer service. Activities to know what is important to the customer is called Customer Value Analysis (CVA) whose process consists of: 1) Determining more important attributes for the customer, 2) Assessing the importance of the attribute, 3) Assessing the company's achievement from the list of priority attributes ,4) Asking the customer to compare all the attributes of the service company with the same attributes of the competitor's service, 5) Repeating the process at any given time.

Value is an idealism. In value, there is a relationship between products and prices. Value comes from the difference between the benefits and costs of the product. The most important value is perceived value, not the actual value. Indeed, high object values are easily communicated to form a high-value perception. However, the relationship is not automatic. Perception differs from reality. Reality in the eyes of customers is what they perceive. Therefore, in marketing perception is reality.

Discussion about customer value was also raised by Petrick (2002). He argues that in order to increase customer loyalty, the company must increase the satisfaction of each customer. To increase customer satisfaction and loyalty, companies must add value that can get them what they pay or more than they expect, so they can survive and lead to repeat purchases and an increase in the proportion of purchases.

\section{Product attribute}

Product attributes have a major effect on buyer's perception of the product. This is because the physical attribute of the product brings a wide range of benefits needed and desired by buyers. Therefore, every company must be careful in making decisions related to attributes.

According to Kotler and Armstrong (2014), it is argued that the development of products and services requires defining the benefits offered. These benefits are then communicated and delivered through product attributes such as product quality, product features and product style and design. Meanwhile, according to Kotler (2006) product attributes are factors considered by the buyer when purchasing the product, such as price, quality, completeness of function, design, after sales service and others. Dimensionalities of product attributes by Garvin (1987) and Zeithaml (1988) are: Performance or product display, Features or additional product characteristics, Product durability, Product price and Brand. 


\section{Image}

Kotler (2006) revealed that the image is the impression someone has about an object or item as a whole. Kotler's definition indicates that individual and group images perceive a phenomenon whereas the image has been defined as a perception of organization as reflected in the associations stored in consumer memory. From the above understanding that the image can be interpreted as a perception or impression someone has on a particular phenomenon.

Every business enterprise seeks to create a good image in the eyes of consumers because the impression consumers to a store will have an important effect on the success of the store. With a good image then the store will be able to attract more consumers. According to Bellenger \& Goldstrucker in Bloemer and Schroder (2002): "A store image can be defined as the customer's perception of the store versus competitive stores". So, it can be interpreted that image of store is how perception of consumer to a store compared to another store. Each consumer has a different perception between one store to another depending on the image of each store.

A company will be seen through its image both negative and positive image. A positive image will give a good sense of the company's products and it can increase the number of sales. Instead sales of a company's products will fall or lose if its image is viewed negatively by the community (Mardalis, 2005). Sunter in Mardalis (2005) believed that in the future customer will be able to distinguish a product with other products just by seeing the image. Therefore, it is important for a company to have a good image. By employing a good concept, a company can complete a good identity and it will ultimately can lead to a high awareness, loyalty, and a good reputation. Oloughlin and Coenders (2002) stated that corporate image is formed due to customer opinions about the overall quality of management, opinions about the company's contribution to society and opinions on the quality of goods / services. Bloemer and Odekerken (2000), stated that store image is built from elements of retail marketing mix consisting of: location, merchandise, store atmosphere, display of goods, price, advertising, personal selling, and incentive program.

\section{Hypotheses Development}

Bennur and Jin (2009) concluded that product attributes affect customer satisfaction and loyalty. Corsi and Rungie (2010) show that there is a positive and significant relationship of product attributes to consumer loyalty with stronger prices and packaging interacting in determining consumer loyalty. The same results are shown by Rajaguru and Matanda (2010) who found the evidence that product attributes such as product quality, price and availability of new products have a significant effect on customer loyalty. Based on the result of empirical research hence this research hypothesis formulated is as follow: H1 Product attribute significantly influences customer loyalty.

Kotler and Armstrong (2014) argue that brand names will help consumers to identify products / services so they can feel the benefits, and the brand will explain the quality of the product / service to the buyer. Walter, A. et al (2002) and Gwin (2007) showed that there was an effect between product attributes on customer value, while the research conducted by Luarn and Lin (2003) and Lee and Murphy (2008) showed that the value affects customer loyalty. With regard to the result of empirical research hence this research hypothesis formulated is as follows:

H2: Customer value mediates the effect of product attributes on customer loyalty

A product can satisfy consumers when it is judged to meet or exceed their desires and expectations (Spreng et al., 1996). Spreng et al. (1996), Mital. et al. (1998), Bei and Chiao (2001) show that there is an effect between product attributes on customer satisfaction, while research conducted by Bloemer, et al. (1998), Oloughlin and Coenders (2002) and Luarn and Lin (2003) showed that customer satisfaction affects customer loyalty.

With regard to the result of empirical research hence this research hypothesis formulated is as follows:

H3 : Customer satisfaction as mediation affects product attribute on customer loyalty

Aaker and Keller (1990) show that a good image of the company is able to increase the satisfaction of consumers of the company's products which then affect on its loyalty. Andreassen and Lindested (1997) concluded that the company's image is positively related to consumer loyalty. Lu and Cai (2009) stated that image affects loyalty. The same results are presented by Cheng (2011) stating that loyalty attitude is 
influenced by service quality, store image, switching cost and customer satisfaction. With regard to the result of empirical research hence this research hypothesis formulated is as follows:

H4: Image has a significant effect on customer loyalty

Good store image in the eyes of consumers creates a good store name also. The image of a store is a perception of the store. A positive consumer perception of the store will create a continuous acceptance of quality to the acceptance of value and the end product is the desire to buy the subsequent repeat purchase (Dodds, Monroe and Grewal, 1991). Andreassen and Lindested (1997) and Chang and Luan (2010) showed that there is an effect between image and customer value, while research by Luarn and Lin (2003) and Lee and Murphy (2008) showed that customer value affects customer loyalty. Based on the result of empirical research hence the research hypothesis formulated is as follows:

H5 Customer value mediates the effect of image on customer loyalty

Research conducted by Andreassen and Lindested (1997) and Bloemer, et al. (1998) showed that there is an effect between image to customer satisfaction while research conducted by Bloemer, et al. (1998), Oloughlin and Coenders (2002), Luarn and Lin (2003) and Cristobal, et al. (2007) showed that customer satisfaction affects customer loyalty. Based on the result of empirical research hence the research hypothesis is formulated as follows:

H6 Customer satisfaction mediates the effect of image on customer loyalty

\section{Research Methods \\ Research Population and Sample}

The population of this research is a shopping mall in the existing hypermarket of Malang, namely, Carrefour, Giant and Matahari hypermat. The population in this research is an infinite population. The size of the population is very large, and the number can not be known for sure. The sample size used was $24 \times 5=120$ respondents. Once the number of samples as much as 120 respondents was determined, then they were distributed on three hypermarket namely, Carrefour, Giant and Matahari hypermat in Malang. In order to be equally distributed on three hypermarkets, the total of 120 samples was divided into 3 hypermarket locations, so that each hypermarket was taken as many as 40 respondents. The details of the number of samples shown in Table 1 are as follows:

Table 1Distribution of Research Samples

\begin{tabular}{lll}
\hline No. & Location & Sample \\
\hline 1 & Carrefour & 40 \\
2 & Giant & 40 \\
3 & Matahari hypermat & 40 \\
\hline Total & & 120 \\
\hline
\end{tabular}

Table 1.Distribution of Research Samples

Source: Primary data processed

After determining the number of samples in each hypermarket, then sampling was done by technique of Convenience sampling. The sample was taken based on spontaneity factor, meaning that anyone who met with the researcher and in accordance with the target population, then the person can be used as sample. To avoid sampling error, the criteria of the target population are determined: 1) The minimum age is of 18 years which is based on the assumption that the respondent is independent in giving the answer because they have been considered as adults, 2) the decision maker is true as customers who make the decision to shop at Carrefour, Giant and Matahari hypermat and 3) they are willing to be interviewed in place and time as agreed

\section{Operational Definition of Variables}

The operational definition of a variable is a research element that tells how to measure a variable that contains an indicator that allows the researcher to collect relevant data for that variable. The operational definitions of variables and indicator variables are presented in table 2 . below: 


\begin{tabular}{|c|c|c|}
\hline Variable & Indicators & Sources \\
\hline Product attribute & $\begin{array}{l}\text { Product quality } \\
\text { The completeness of product } \\
\text { Product packaging } \\
\text { Product price }\end{array}$ & $\begin{array}{l}\text { Garvin (1987), Zeithaml (1988), } \\
\text { Newman, et al, (2002), Gwin, } \\
\text { (2003) dan Kotler dan } \\
\text { Armstrong (2006) }\end{array}$ \\
\hline \multirow[t]{2}{*}{ Image } & $\begin{array}{l}\text { Location accessibility } \\
\text { Price appropriateness }\end{array}$ & $\begin{array}{l}\text { Ghosh, A. (1994), Bloemer and } \\
\text { Schroder (2000) }\end{array}$ \\
\hline & $\begin{array}{l}\text { Employees hospitality } \\
\text { Location comfort } \\
\text { Interesting Display }\end{array}$ & \\
\hline Cutomer value & $\begin{array}{l}\text { Shopping enjoyment } \\
\text { length of time needed for Shopping } \\
\text { Prestigious value of shopping } \\
\text { Price appropriateness and quality } \\
\text { Payment easiness }\end{array}$ & $\begin{array}{l}\text { Butz and Goodstein (1996), } \\
\text { Thurau et.al., (2002); dan Lam } \\
\text { et.al., (2004) }\end{array}$ \\
\hline Customer satisfaction & $\begin{array}{l}\text { Expectation fulfillment } \\
\text { The appropriateness of product } \\
\text { quality and expectation } \\
\text { The appropriateness of product price } \\
\text { and expectation } \\
\text { Satisfaction and service }\end{array}$ & Maxwell K. Hsu et al (2010) \\
\hline & Sat is faction and comfort & \\
\hline Customer loyalty & $\begin{array}{l}\text { The best choice for shopping } \\
\text { The first choice for shopping } \\
\text { The loyalty toward hypermarket } \\
\text { The will to always shop at } \\
\text { hypermarket } \\
\text { Recommend hypermarket to families } \\
\text { and friends }\end{array}$ & $\begin{array}{l}\text { Trang T.M. Nguyen, et al } \\
\text { (2007) dan Chen (2008) }\end{array}$ \\
\hline
\end{tabular}

Table 2. Research Variables and Indicators

\section{Data analysis method}

In relation to research problem, research objectives and research hypothesis, the data analysis used in this research was done using variance based or component based with Partial Least Square (PLS) approach. Testing $\mathrm{t}$ - Statistics is said to be significant if the value of $\mathrm{t}$ arithmetic is in the critical area so that hypothesis 0 is rejected and vice versa testing is not significant if the $t$-statistic value is in the réception area. Statistical test results are said to be significant if the value of $t$ arithmetic $>t$ table, so the null hypothesis is rejected or hypothesis is accepted. Furthermore, table distribution of $\mathrm{t}$ table for significance level testing $\alpha=5 \%$ is equal to 1,960

\section{Results}

There are basically four hypotheses used in this research. Therefore, to conclude whether the proven research hypothesis, used cut-off value tcount $=1.960$. Thus, if tcount on the path tested $\geq 1.960$, then the research hypothesis proved. The results of hypothesis testing in detail can be seen in table 3 below.

\begin{tabular}{llll}
\hline The influences among variables & $\begin{array}{l}\text { Path } \\
\text { coefficient }\end{array}$ & $\begin{array}{l}\text { T } \\
\text { Statistics }\end{array}$ & Note \\
\hline Product attribute $\rightarrow$ Customer value & 0,520 & 5,115 & Sig \\
Image $\rightarrow$ Customer value & 0,246 & 2,116 & Sig \\
Product attribute $\rightarrow$ customer satisfaction & 0,299 & 2,928 & Sig \\
Image $\rightarrow$ customer satisfaction & 0,160 & 2,122 & Sig \\
Product attribute $\rightarrow$ customer loyalty & 0,205 & 2,089 & Sig \\
Image $\rightarrow$ customer loyalty & 0,009 & 0,073 & Not Sig \\
Customer value $\rightarrow$ customer loyalty & 0,587 & 5,338 & Sig \\
Customer satisfaction $\rightarrow$ customer loyalty & 0,178 & 2,270 & Sig \\
\hline
\end{tabular}

Table 3. Récapitulation of Hypothèses Testing Results 
Analysis Model of the complete direct effect will be clearly seen on the following figure:

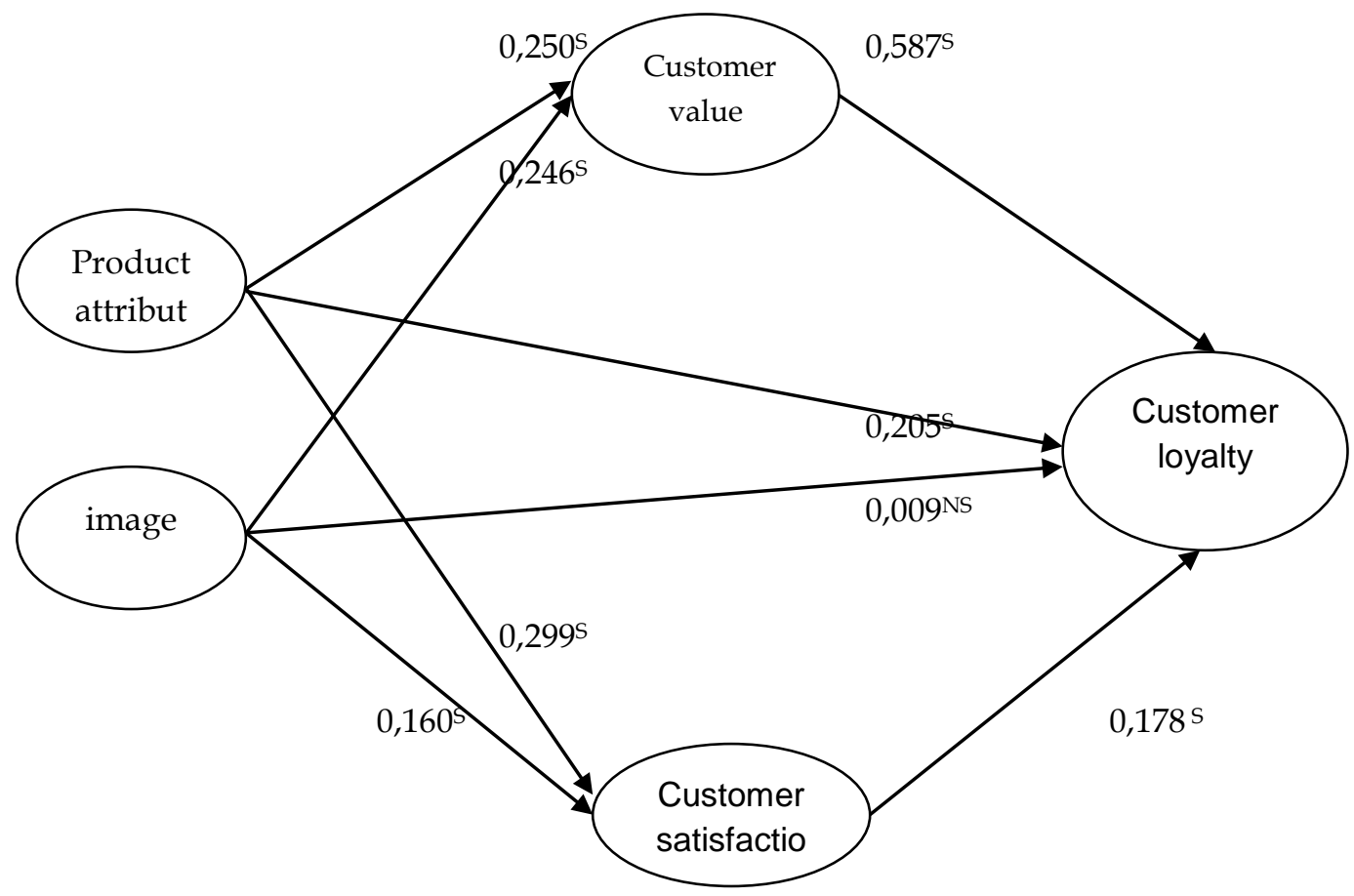

Figure 1. The effect of Product attributes on customer loyalty.

Based on the results of inferential statistical analysis, it shows that product attributes significantly influence customer loyalty. It can be said that the retail business in the modern market format experienced rapid growth in Malang. This growth is caused by various factors, namely population growth, economic growth, technological developments, lifestyle changes of Indonesian people in conducting consumption activities, and globalization. The entry of large companies, such as Carrefour, Hypermart, and Giant, making the competition in retail business in Malang becomes increasingly tight. In order to compete, the retailer must create a strategy which is not only focused on capturing customers or satisfying customers in the moment, but also creating customer loyalty. Customer loyalty is an important factor in retail business success and the survival of a retail. Without customer loyalty in a retail business, then the competitive advantage possessed will not be successful.

According to Griffin (2005), the rewards of loyalty are long-term and cumulative. The longer the customer's loyalty, the greater the profit earned from that customer. Conversely, switching customers can cost companies because the cost of serving and selling goods to old customers is lower than that of new customers. To obtain the loyalty of hypermarket customers in Malang, hypermarket products must have good quality in terms of completeness of various products sold, such as household needs, food and including daily necessities, textiles, fashion, furniture, so that the completeness of the product has given its own place in the eyes of consumers. In addition, packaging uses its own packaging and brand at a cheaper price so that it appeals to customers.

Product attributes are factors that buyers consider when buying products. The factors considered include price, quality, packaging, functionality (features), design, service and after sales. If a product has attributes or traits appropriate to what its buyer expects then the product will be considered suitable and will be followed by repeated purchase actions by the consumer.

The results of this research elaborate the research finding conducted by Bennur and Jin (2009) which concluded that product attributes affect customer satisfaction and loyalty. Corsi and Rungie (2010) showed that there is a positive and significant relationship of product attributes on consumer loyalty stating that stronger prices and packaging will interact in determining consumer loyalty. The same results 
are shown by Rajaguru and Matanda (2010) who found the evidence that product attributes such as product quality, price and availability of new products have a significant effect on customer loyalty.

Customer value mediates the effect of product attributes on customer loyalty. Based on the results of inferential statistical analysis, it shows that customer value acts as partial mediation from the indirect effect on the effect of product attribute on customer loyalty. In relation to these results, the role of mediation is smaller when compared to the direct effect of product attributes on customer loyalty, due to nonconformance factors over product attributes sold in hypermarkets. This happens because the products sold have the same quality and brand as products sold in supermarket, so customers have already recognized brand products. This is supported by the characteristics of customers who are more educated and more informed than ever. Customers verify the company's claims and look for better alternatives, so customers tend to maximize the value they get, with cost constraints, limited knowledge, mobility, and revenue. The customer estimates which bid gives the highest perceived value. The discussion of customer value was also stated by Petrick (2002) stating that in order to increase customer loyalty, the company must increase the satisfaction of every customer. In other words, to increase customer satisfaction and loyalty, companies must add value that can get them what they pay or more than they expect, so they can survive and lead to repeat purchases and an increase in the proportion of purchases.

Woodruff, (1997) argued that the concept of customer value provides an overview of a company's customers, considers what they want, and believes that they benefit from a product. Likewise, Goetsch and Davis (2000) stated that organizations or companies should know what customers want and what product or value of service that customers expect. Kotler and Armstrong (2014) argued that brand names will help consumers to identify products / services so they can feel the benefits, and the brand will explain the quality of the product / service to the buyer.

Walter, A. et al. (2002) and Gwin (2007) concluded that product quality influences the value of customer relationships. Luarn and Lin (2003) in their research found the evidence that perceived value affects customer loyalty. Lee and Murphy (2008) concluded that customer value affects loyalty. Furthermore, Gwin, (2007) proved that there is a relationship between trust and brand quality and will have an effect on perceived value and loyalty to the brand.

\section{Customer satisfaction in mediating the effect of product attributes on customer loyalty}

Based on the result of inferential statistic analysis, it found out that customer satisfaction acts partially in mediating the indirect effect of product attribute to customer loyalty. In relation to these results, the role of mediation is smaller when compared to the direct effect of product attributes on customer loyalty. This might happen due to nonconformance factors over product attributes sold in hypermarkets have the quality and brand side of the products sold in sepermarket. Thus, customers have already recognized brand of the product. This condition causes attributes of products sold in hypermarket will actually directly provide loyalty without going through customer satisfaction. This customer loyalty is formed due to the fact that hypermarket has a complete range of products sold so it is considered as the best choice for shopping or in other word this reflects customer loyalty.

The results of this research extend the research conducted by Mital. et al. (1998) stating that poor performance on product attributes has a negative effect on overall satisfaction and positive performance on product attributes has a positive effect on the same attribute and overall satisfaction indicates a reduction in sensitivity at attribute performance levels. The same results are shown by a research conducted by Spreng et al. (1996), Bei and Chiao (2001) showing that there is an effect between product attributes on customer satisfaction. Mean while, a research conducted by Bloemer, et al. (1998), Oloughlin and Coenders (2002) and Luarn and Lin (2003) showed that customer satisfaction affects customer loyalty.

Meanwhile, in terms of customer loyalty, Anderson et al (1994) states that if the customer is satisfied with the product or service provided, it will lead to customer loyalty that makes the customers repurchase in the future and this also hampesr the competitor to attract customers because customers are reluctant to switch, lower the cost and time of subsequent transactions, lower the cost of handling product / service mismatches, reduce new customer search costs because customers will tend to inform other potential customers informing that the company has satisfactory products and services.

www.jbrmr.com A Journal of the Academy of Business and Retail Management (ABRM) 


\section{Image has a significant effect on customer loyalty}

Based on the inferential statistical analysis, it was found out that hypermarket Based on the results of inferential statistical analysis, it shows that hypermarket image is not able to contribute significantly to customer loyalty.

The image in general is a psychological image that is formed in the minds of consumers resulting from many different stimuli to each of their senses. Bombarded with a positive store image, word-of-mouth information can cause a person to be interested and immediately visit the store. The better the image of the store in the eyes of the consumers, the greater the impulse buying made by the consumer and vice versa. The strong effect of store image characteristics consists of: assortment, atmosphere, location to increase the number of customers and make it as a regular customer of the company, as well as having a positive experience to increase satisfaction perceived by customers (Bloomer and Schroder, 2002).

In a research conducted by Bloemer and Ruyter (1997) on the image of a store, it was explained that the real image is a complex perception of the customer regarding the store based on some attributes attached to it. The customer will assess the attributes by viewing, hearing and feeling, and then the results of those activities will be compared to the information previously obtained from other customers and then used as the basis for evaluating the company (Bontis and Booker 2007).

The absence of the effect of the image of customer loyalty is probably caused by hypermarket image which is associated with reasonable price. It means that prices offered are in accordance to the quality of goods and attributes attached to the goods are the same as the conditions that existed at the supermarket. This what makes the customers do not have the same loyalty level concerning the imaging activity that has been done. These results are in line with the opinions expressed by Bloemer, et al. (1998) stating that the image has no effect on loyalty.

This result is inconsistent with research conducted by Andreassen and Lindested (1997) stating that the company's image is positively related to customer loyalty. Furthermore, Oloughlin and Coenders (2002) concluded that the image had an effect on loyalty and on the same tone Lu and Cai (2009) concluded that the image affected loyalty.

The customer value which serves as mediation gives an effect on the image on customer loyalty

Based on the results of inferential statistical analysis, it shows that mediation of customer value is full (complete mediation) from the indirect effects between images effect on customer loyalty. In other words, it I said that customer loyalty increases when the image of hypermarket is capable of delivering value to customers. These results explain that customers will have high loyalty when the image of the hypermarket is in accordance to the price offered and the quality of goods and attributes attached to the goods are able to deliver value to customers like shopping at hypermarkets is a prestigious so that customers will have no objections concerning the costs incurred. To get loyal customers, every retail must create a good image in the eyes of consumers, because the image that consumers have toward the store will ultimately lead to consumer ratings of the existence of the store. Fostering and maintaining a strong image is essential for a service organization, if it is to attract consumers and maintain its loyalty.

Dodds and Grewal, (1991) revealed that a good store image in the eyes of consumers creates a good store name as well. The image of a store is a perception of the store, where if the positive consumer perception of the store will create a continuous acceptance of quality to the acceptance of value and the end product is the desire to buy the later repeat purchase. Andreassen and Lindested (1997) and Chang and Luan (2010) show that there is an effect between image and customer value, while research by Luarn and Lin (2003) and Lee and Murphy (2008) show that customer value affects customer loyalty.

Customer satisfaction as mediating the effect of image on customer loyalty

Based on the result of inferential statistic analysis resulted that customer satisfaction acts as mediation is full (complete mediation) from indirect effect effect between image to customer loyalty. These results can be explained that the customer will have a high level of loyalty if hypermarket image that is identified with the price offered in accordance with the quality of goods and attributes attached to the goods have been in accordance with the expected hypermarket customers.

The image of the store is the customer's perception of the store and its attributes. Each of these attributes will form a different image in the eyes of consumers. A company will be seen through its image both negative and positive image. A positive image will give a good sense of the company's products and 
so can increase the number of sales. On the contrary, sales of a company's products will fall or lose if its image is viewed negatively by the community.

The results of this research reinforce the research conducted by Aaker and Keller (1990) stating that a good image of the company is able to increase customer satisfaction of the company's products which then affect on loyalty. Andreassen and Lindested (1997) showd that the company's image is positively related to the perception of quality, consumer satisfaction, and consumer loyalty.

\section{Conclusion}

To conclude, customer will have high loyalty level to hypermarket if products sold at hypermarket have good quality in terms of completeness of various product sold, such as household needs, food and including daily requirement, textile, fashion, furniture, so that the completeness of the product has given its own place in the eyes of consumers. In addition, having private brand and packaging can make the products sold at cheaper price so that it appeals to customers. The role of customer satisfaction as mediation is smaller when compared to the direct effect of product attributes on customer loyalty. The condition is because products sold at hypermarket in terms of quality and brand is the same as the products sold in supermarket so that customers have already recognized the product brand. Image can not contribute to the loyalty of hypermarket customers in Malang. This condition is caused by hypermarket image associated with a reasonable price. It means that the price offered is in accordance to the quality of goods and attributes attached to the goods and it is the same as the condition of products sold at $\mathrm{f}$ the supermarket. This what makes the customers do not have the level of loyalty concerning the imaging activity done. The value of customers can mediate the effect of the image on the loyalty of hypermarket customers in Malang. These results can be explained that customers will have high loyalty when the image of the hypermarket is identified with the price offered is in accordance to the quality of goods and attributes attached to the goods are able to deliver value to customers like shopping at hypermarkets is a prestigious so that costumers will have no objections regarding the costs incurred. Customer satisfaction can mediate the effect of the image on the loyalty of hypermarket customers in Malang. These results explain that customers will have a high level of loyalty if hypermarket image that is identified with the price offered and the quality of goods and attributes attached to the goods have been in accordance to the expectation of hypermarket customers.

There are some suggestions or managerial implication proposed in this research. First, it is noted that the mediation role of customer satisfaction on the effect of product attributes on customer loyalty hypermarket in Malang is relatively small in number. The implication is that hypermarket management needs to pay attention to customer satisfaction indicators, especially indicators related to the level of comfort to increase customer loyalty as choosing various products sold required a convenience. The image directly does not affect the loyalty of hypermarket customers in Malang. The implication is that hypermarket management needs to pay attention to the image indicator especially things related to the placement of the display is made as attractive as possible so that the customer is interested to take and buy the goods offered, the condition that can increase customer loyalty. For future research it is advisable to add other variables such as customer trust as a moderator variable so that it can further complement this research

\section{Acknowledgements}

The researcher would like to thank the editors and Reviewer of Journal of Business and retail Management Research for their advice, very detailed feedback in improving the quality of the article. It is a pleasure for the researcher is able to be given the opportunity to contribute articles in the journal of Business and retail Management Research. This research is supported by Brawijaya University, Economics and Business Faculty. Usual disclaimers apply.

\section{References}

Aaker, D.A., \& Keller, K, L, (1990), Consumer Evaluations of Brand Extension. Journal of Marketing, 54 (January),27-41. Anselmson, J, (2006). Sources of customer satisfaction with shopping malls: a comparative study of differ customer segments. Journal Review of Retail, Distribution and Customer Research, Vol. 16, No. 1, pp. 155-138.

Beneke, J., Adams, E., Demetriou, O., Solomons, R., (2011), An Exploratory Study of the Relationship Between Store Image, Trust, Satisfaction and Loyalty in a Franchise Setting. Southern African Business Review. Vol. 15, No. 2, pp. 59-74. 
Bennur, S., \& Jin, B., (2009), From Apparel Product Attributes to Loyalty: A Proposed Framework Using Kano's Theory. International Textile and Apparel Association, USA

Bloemer \& Ruyter,. (1998), On the relationship between store image, store satisfaction and store loyalty. European Journal of Marketing, Vol. 32, No. 5/6, pp. 499-513

Bloemer, J., \& Schroder, G., (2002). Store Satisfaction and Store Loyalty Explained by Costumer and Store-Related Factors. Journal of Consumer Satisfaction, Dissatisfaction and Complaining Behavior, 15, pp. 451-450.

Bloemer \& Odekerken., (2000), The Influence of Store Image and Relationship Proneness on Store Loyalty, Eoropean Journal of Marketing, 32, pp. 499-513

Chan, S., (2003), Relationship Marketing. Jakarta: Gramedia Pustaka Utama

Chen, H. C., Robert, D, G., \& James, M., (2008), Male and Female Influence on Hypermarket Brand Equity. International Business \& Economics Research Journal, Vol, 7, Number 9.

Cheng, S., I, (2011), Comparisons of Competing Models between Attitudinal Loyalty and Behavioral Loyalty. International Journal of Business and Social Science, Vol, 2 No,10

Cooil, B., Keiningam, T., Aksoy, L, \& Hsu, M, (2007), A longitudinal analysis of customer satisfaction and share of wallet: Investigating the moderating effect of customer characteristics, Journal of Marketing, Vol, 71, No. 1, pp. 67-83.

Corsi, M. A., \& Rungie, C, (2010), The Evolution of The Relationships Between Product Attributes in Determining Consumers behavioural Loyalty. Anzmac Journal. Page 1-51

Dodds, W, B., Kent B, M., \& Dhruv, G, (1991), Effects of Price, Brand, and Store Information on Buyers Product Evaluation, Journal of Marketing Research, 28 (August): pp, 307-319.

Dong, M, K., (2003), Inter-relationships among Store Images, Store Satisfaction, and Store Loyalty among Korea Discount Retail Patrons. Asia Pacific Journal of Marketing and Logistics, Vol. 15 Issue: 4, pp.42-71

Fornell, C, Johnson, M, D., Anderson, E, W, \& Bryant, B, E., (1996), The American Customer Satisfaction Index: Nature, Purpose, and Findings, Journal of Marketing, Vol.60

Foster, B, D., \& John, W, C., (2000), Relationship Selling and Customer Loyalty: An Empirical Investigation, Marketing Intelligence \& Planning. Vol, 18, No 4, pp. 185-199.

Garvin, D., (1987). Competing on the Eight Dimensions of Quality. Harvard Business Review 65, no. 6 (NovemberDecember 1987).

Goetsch \& Davis, (2000), Introduction to Total Quality, Englewood Cliffts: Prentice-Hall Inc.

Griffin, J., (2002), Customer Loyalty: How To earn it, How to Keep it, Published by Jossey-Bass, Inc., a John Willey\&Sons, Inc. Company USA.

Gwin, C, F., (2007), The Impact of Trust and Brand Relationship Quality on Perceived Value and Loyalty in a Consumer Goods Environment. Pepperdine University, Marketing Department Graziadio School of Business and Management

Kotler, P., (2006), Marketing Management, Twelfth Edition. Pearson Prentice Hall. USA

Kotler, P, \& Armstrong, G, (2014), Principle of Marketing, 15th edition. New Jersey: Pearson Prentice Hall.

Kotler, P, \& Keller, K, L., (2012), Marketing Management 13. New Jersey: Pearson Prentice Hall, Inc.

Lee, R., \& Jamie, M, (2008) The Moderating Influence of Enjoyment on Customer Loyalty. Australasian Marketing Journal $16(2)$.

Luarn, P, \& Hsin, H, L, (2003), A Customer Loyalty Model for E-Service Context, Journal of electronic Commerce, Vol. 4, pp. 156-168.

Lu, Y, \& Cai. A, L, (2009), Analysis of Image and Loyalty for Exhibitions and Host Destinations. International CHRIE Conference-Refereed Track. Paper 15.

Maxwell, K, H, Yinghua, H, \& Scott, S., (2010), Grocery store image, travel distance, satisfaction and behavioral intentions Evidence from a Midwest college town. International Journal of Retail \& Distribution Management. Vol, 38, No, 2, pp. 115-132

Ming, T, T., Chung, L, T, \& Han, C, C, (2010), The Effect of Customer Value, Customer Satisfaction, And Switching Costs on Customer Loyalty: An Empirical Study of Hypermarkets in Taiwan. Social Behavior and Personality, 38(6), 729-740

Mital, V, William, T, R, \& Patrick, M, B., (1998), The asymmetric Impact of Negative and Positive Attribute Level Performance on Overall Satisfaction and Repurchase Intentions, Journal of Marketing, vol, 62, pp.33-47.

Newman, A, J, \& Cullen, D, (2002), Retailing: Environment \& Operations, Thomson Learning.

Oloughlin, O, C, \& Germa, C, (2002), Application of the European Customer Satisfaction Index to Postal Services. Structural Equation Models versus Partial Least Squares. Departament d'Economia, Universität de Girona

Petrick, J, F, (2002), Development of a Multi-Dimensional Scale for Measuring the Perceived Value of a Service, Journal of Leuisure research, Second Quarter, 34 (2), pp,119-134.

Rajaguru, R, \& Matanda. J, M, (2010), Consumer Perception of Store and Product Attributes and its Effect on Customer Loyalty within the Indian Retail Sector. Australian and New Zealand Marketing Academy (ANZMAC), Brisbane Qld Australia, pp. 1-8.

Reddy, N, R \& Azeem, B, A, (2011), Influence of Store Satisfaction, Merchandise Quality, and Service Quality on Store Loyalty. International Journal of Trade, Economics and Finance, Vol. 2, No. 5 
Richard, M, S, (1994), Building Sales and Company Image. Telemarketing Magazine, vol. 13, p. 86 - 89.

Sirohi, N., Edward W. M., \& Dick R.W, (1998), A Model of Consumer Perceptions and Store Loyalty Intensions for a Supermarket Retailer, Journal of Retailing, 74(2), pp. 223-245.

Slater, S, F, \& Narver, J, C, (1994), Does Competitive Environment Moderate the Market Orientation Performance Relationship, Journal of Marketing, Vol. 58, No. 1, pp. 46-55

Sung, J, Y, \& Young, J, C, (2005), An Exploratory Research on the Store Image Attributes Affecting Its Store Loyalty, Seoul Journal of Business, Volume 11, Number 1

Spraeng, R, A., Mackenzie, S, B., \& Richard, W, O, (1996), A Reexamination of the Determinants of Consumer Satisfaction, Journal of Marketing. 60, pp. 15-32.

Tse, D, K., \& Peter C, W, (1988), Models of consumer satisfaction formation an extension. Journal of Marketing Research. Vol, 25, pp, 204-212.

Trang, T, M., Nguyen, T, N, \& Nigel, J, B, (2007), Hedonic shopping motivations, supermarket attributes, and shopper loyalty in transitional Markets Evidence from Vietnam. Asia Pacific Journal of Marketing and Logistics. 19 No, 3, pp. 227239

Turkyilmaz, A, \& Coskun, O, (2007), Development of a customer satisfaction index model, Industrial Management \& Data Systems, Vol, 107, No, 5 pp, 627-687

Mital, V, William, T, R, \& Patrick, M, B (1998), The Asymmetric Impact of Negative and Positive Attribute Level Performance on Overall Satisfaction and Repurchase Intentions, Journal of Marketing, Vol, 62. Pp,33-47

Walter, A., Thilo A, M., Gabriele, H, , David, T, W, (2002), Delivering Relationship Value: Key Determinant for Customers' Commitment. Institute for the Study of Business Markets Report

Zeithaml, V, A., (1988), Consumer Perceptions of price, quality and value: A means-ends model synthesis of evidence. Journal of the Academy Marketing Science. Vol. 21 